\title{
Distribution and taxonomic notes of Eunotia Ehrenberg 1837 (Bacillariophyceae) in rivers and streams of Northern Spain
}

\author{
Roser Ortiz-Lerín * and Jaume Cambra \\ Departament Biologia Vegetal, Unitat de Botànica. Universitat de Barcelona. Av. Diagonal 645, 08028 Barcelona, Spain. \\ * Corresponding author: roser_ortiz66@yahoo.es
}

\begin{abstract}
Distribution and taxonomic notes on Eunotia Ehrenberg 1837 (Bacillariophyceae) in rivers and streams of Northern of Spain

Between August and October of 2003, a total of 397 samples of epilithic diatoms were collected from different stations belonging to the control network of the North Hydrographical Confederation of Spain (CHN). One hundred and seventeen sites with Eunotia diatom species were found. Galicia, with 78 localities, was the region with higher representation. Eighteen taxa of the Eunotia genus were identified, 17 of them to the species level. Eunotia minor (Kützing), Grunow in van Heurck and Eunotia implicata Nörpel, Lange-Bertalot \& Alles were the most common species, present in $59 \%$ and $50.4 \%$ of the samples, respectively. Conductivity and water acidity were the most important factors in determining Eunotia distribution in the studied area. The main objective of this work was to contribute to the knowledge, from the taxonomic and distribution viewpoints, of the diatoms of the genus Eunotia Ehrenberg that were found in the Iberian Peninsula. It is the first comprehensive study on the Eunotia genus of northern Spain.
\end{abstract}

Key words: Diatoms, Eunotia, distribution, ecology, Northern Spain Basins.

\section{RESUMEN}

Distribución y notas taxonómicas de Eunotia Ehrenberg 1837 (Bacillariophyceae) en ríos y arroyos del norte de España

Entre agosto y octubre del 2003, se recogieron un total de 397 muestras de diatomeas epilíticas en distintas estaciones pertenecientes a la red de control de la Confederación Hidrográfica del Norte (CHN). En un total de 117 localidades se encontraron diatomeas del género Eunotia. Galicia, con 78 estaciones, es la región con más representación. 18 taxones del género Eunotia han sido determinados, 17 de ellos a nivel específico. Eunotia minor (Kützing) Grunow in van Heurck $y$ Eunotia implicata Nörpel, Lange-Bertalot \& Alles han sido las especies con más representación encontrándose en el 59 \% y $50.4 \%$ respectivamente de las muestras. La conductividad y la acidez del agua han resultado ser factores importantes que determinan la distribución de especies del género Eunotia en la zona de estudio. El objetivo principal de este trabajo es contribuir al conocimiento desde el punto de vista taxonómico y de distribución de las especies del género Eunotia Ehrenberg en la península Ibérica. Corresponde al primer trabajo exhaustivo del género Eunotia en el norte de España.

Palabras clave: Diatomeas, Eunotia, distribución, ecología, cuencas del Norte de España.

\section{INTRODUCTION}

Eunotia is the best represented genus of the Eunotiaceae family (Bacillariophyceae) in the Iberian inland waters. This is essentially a freshwater diatom genus frequently associated with acidic waters (Slàdeček, 1986; Patrick,
1948; Descy, 1979; Alles et al., 1991; Cameron, 1995; Carter \& Flower, 1988; Pierre, 1996) and oligotrophic or dystrophic situations (Patrick \& Reimer, 1966; Descy, 1979; Koyabaysi et al., 1981; Lange-Bertalot \& Metzeltin, 1996).

The diatom genus Eunotia is unusual among raphid diatoms in that the raphe slits are short, 
often rudimentary, and not integrated into the primary pattern centre; instead, they lie to one side of it (Mann, 1984; Round et al., 1990). This and other characteristics, particularly the presence of rimoportulae (labiate processes), are consistent with the hypothesis that Eunotia is a basal lineage within the raphid group (Mann et al., 2003). In girdle view they have a characteristic rectangular shape. In valve view they are asymmetrical along the apical axis. Usually the dorsal margin is more or less convex while the ventral margin is straight or somewhat concave.

Eunotia is a large genus that comprises around 200 species (Van Landingham, 1969). The genus has a world-wide distribution, although numerous species are restricted to tropical areas, due to their environmental water preferences: low $\mathrm{pH}$ and conductivity being the most abundant and diverse genus in these areas (Coste \& Ricard, 1982; Torgan \& Delani, 1988; De Oliveira \& Steinitz-Kannan, 1992; Metzeltin \& Lange-Bertalot,1998; Sala et al., 2002; Díaz-Castro et al., 2003).

Despite its abundance in freshwater habitats, literature concerning Eunotia species is scant. There are few studies about the specie's valve structure; we can find some references on fine structure for 52 Eunotia species in the bibliographic compilation of Gaul et al. (1993). Some studies have pointed out that the difficulties on the identification of the species of Eunotia are due to its great variability in the size and shape of the valve throughout the life cycle (Mayama, 1992; Mayama \& Kobayasi, 1991). This morphological variation is associated with size reduction during the vegetative cell division (Round, 1972), or appears to be more a function of the clone genotype than the environmental conditions (light intensity, temperature, and agitation) (Steinman \& Sheath, 1984). On the other hand, there are unsolved taxonomical problems because of resemblances between different taxa (Mayama, 1997), and those difficulties increase with very small species (Petersen, 1950). However, Krammer \& Lange-Bertalot (1991) have done a modern and exhaustive revision of the group on materials collected in European temperate environments, which has made the identification of some Eunotia species easier.

From an historical point of view, papers on diatoms in the studied area are scarce, some

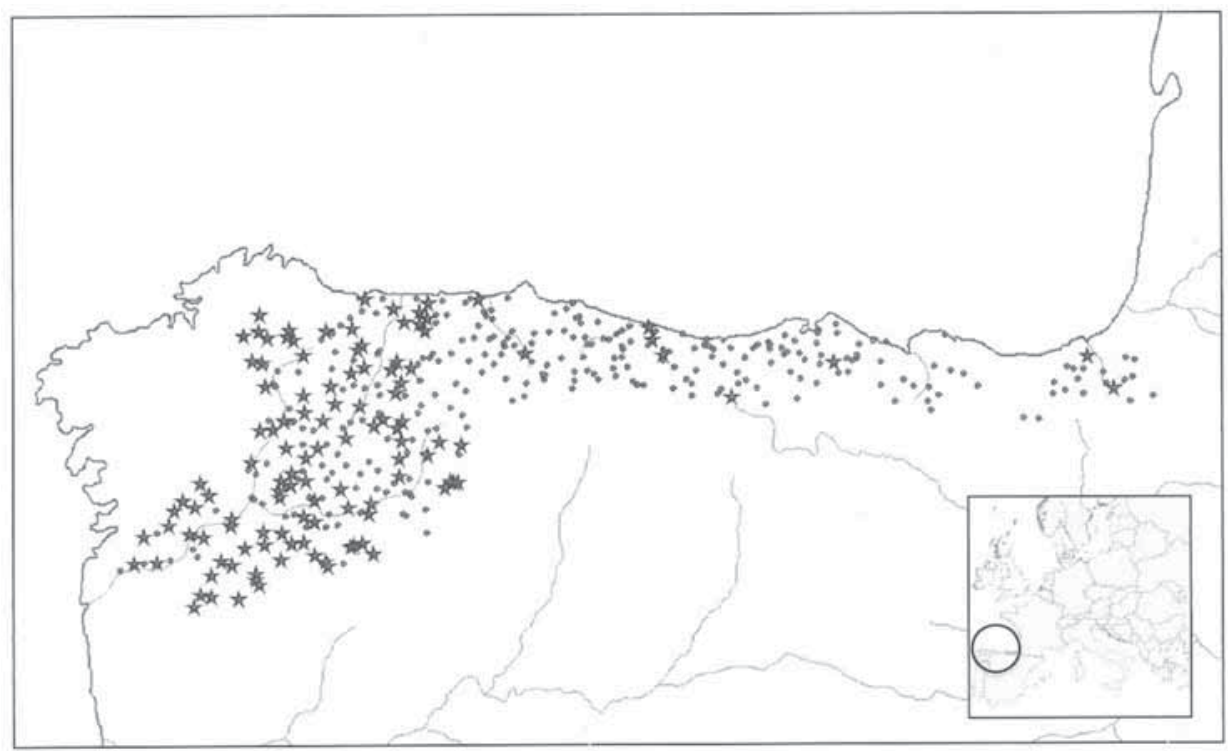

Figure 1. Geographical distribution of the 397 sites where epilithic diatoms were sampled (filled circles) and the 117 localities where Eunotia (Bacillariophyceae) species were found (filled stars). Localización geográfica de las 397 localidades donde se han muestreado diatomeas epilíticas (círculos llenos) y las 117 localidades donde se han encontrado especies del género Eunotia (Bacillariophyceae) (estrellas llenas). 
disperse studies have been published so far by Trúan (1885), West (1911), and GonzalezGuerrero (1942). The first important contribution to the diatom flora of this area was performed by Margalef (1946, 1950, 1956a, 1956b, 1958). In recent years, doctoral theses (Alonso-Fernández, 1989) and reports to assess running water quality by using diatoms (Antelo, 1991; Ector et al., 1992; Aboal et al., 2003b) were carried out in this zone, increasing the knowledge of benthic diatom flora. Nevertheless, the genus Eunotia has not been studied in detail in this region.

The aim of this study is to present a taxonomic description of the Eunotia species found and to give an account of their ecological preferences and distribution in the studied area; it represents the first comprehensive Eunotia study of northern Spain.

\section{STUDY AREA AND METHODS}

The studied area is located inside the Water Quality Surveillance Network of the North Hydrographical Confederation of Spain (CHN). It comprises a total length of $9000 \mathrm{~km}$ with an area of $38,384 \mathrm{~km}^{2}$. It includes all the rivers and streams which run into the Cantabrian Sea and the Atlantic Ocean in the North of Portugal, excluding those rivers which flow entirely in Galicia and the Basque Country. Diatom samples were collected in different ecotypes due the habitats heterogeneity in the studied basins. The sites were determined taking into account the main rivers in order to have a great representation of geographic areas and eco-regions. Miño, Nalón, Navia, Nervión and Limia were the best represented basins.

A single sample per site was collected between August and October 2003 in 397 stations (Fig.1). Epilithic diatom samples were taken and treated and permanent diatom slides were prepared following standard methods (European Committee for Standardization 2003, 2004). At least 5 small submerged boulders from the main flowing water and well-lighted part of the river were brushed to collect diatoms. Samples were preserved in $4 \%$ formaldehyde. Organic matter was eliminated by oxidation with hydrogen peroxide to obtain clean frustule suspension. Diluted hydrochloric acid was added to remove the calcium carbonate in order to avoid late precipitation, which could make frustule observation and counting difficult. After distilled water cleanings, permanent slides were then mounted on cover slips with Naphrax $\AA$ for examination by light microscopy (LM) using an oil-immersion lens at 1000x magnification. A complete taxa list was made and a minimum of 400 valves from each slide were counted to calculate species relative abundance (Prygiel \& Coste, 1993). These data were processed with the software OMNIDIA, version 4.1 (Lecointe et al. 1993, 1999), which provided the resulting values for 13 diatoms water quality indices per each inventory. In order to estimate the pollution level of the sampling sites we chose the Specific Pollution Sensitivity Index (SPI, Coste in Cemagref, 1982). The SPI is considered a general pollution evaluator. This index is based on the Zelinka \& Marvan formula (Zelinka \& Marvan, 1961), which is a weighted average of species indicator values. This index has been chosen because SPI has usually been considered as the reference index for long time (Descy $\&$ Coste, 1991). It has already been tested in the Iberian Peninsula rivers (e.g. Sabater, 2000; Almeida, 2001; Gomà et al., 2004; 2005) with successful results and it takes into account all known taxa. The index range is from 1 to 20,1 being the worst quality and 20 the best.

Samples with a total percentage of Eunotia species higher than $15 \%$ were examined by scanning electron microscopy (SEM). SEM was carried out with a Hitachi S-2300 operated at $10 \mathrm{Kv}$. Photographs were taken of taxa with LM or SEM when possible. Conductivity and $\mathrm{pH}$ were measured in situ using multi-parametric sensors.

To describe the $\mathrm{pH}$ preferences of each Eunotia species identified, we used the $\mathrm{pH}$ classification of van Dam et al. (1994) which is derived from Hustedt (1938-1939), who used the term acidobiontic for diatoms having their $\mathrm{pH}$ optimum at $\mathrm{pH}<5.5$; acidophilus when mainly occurring at $\mathrm{pH}<7$; circumneutral for diatoms having their $\mathrm{pH}$ optimum around 7 ; alkaliphilous when mainly occurring at $\mathrm{pH}>7$ and alkalibiontic when exclusively occurring at 
Table 1. List of the collecting sites in the studied area from which Eunotia species had been found with abundances over $5 \%$, indicating the site code, river, region, basin, and village. The sites are ordered from higher to lower abundance in Eunotia species. Lista de las localidades estudiadas donde las especies de Eunotia presentaron una abundancia superior al $5 \%$, indicando el código de estación, río, región, cuenca y localidad. Las localidades están ordenadas de mayor a menor abundancia en especies de Eunotia.

\begin{tabular}{|c|c|c|c|c|c|}
\hline SITE CODE & RIVER & REGION & BASIN & VILLAGE & \% EUNOTIA \\
\hline MI-078 & CAYOSO & GALICIA & MIÑO & CARBALLEDA & 69.70 \\
\hline MI-004 & TAMOGA & GALICIA & MIÑO & ABADIN & 56.13 \\
\hline MI-500 & LABRADA & GALICIA & MIÑO & GUITIRIZ & 51.34 \\
\hline EO-001 & CUBILLEDO & GALICIA & $\mathrm{EO}$ & BALEIRA & 42.43 \\
\hline MI-117 & RUBIN & GALICIA & MIÑO & PUEBLA DEL BROLLON & 38.06 \\
\hline MI-002 & SAN MARTIN & GALICIA & MIÑO & VILLALBA & 30.02 \\
\hline MI-005 & TAMOGA & GALICIA & MIÑO & VILLALBA & 28.88 \\
\hline MI-138 & ARNOYA & GALICIA & MIÑO & BAÑOS DE MOLGAS & 27.91 \\
\hline NA-027 & AVIOUGA & ASTURIAS & NAVIA & IBIAS & 25.62 \\
\hline NAL-029 & PUMAR & ASTURIAS & NALON & CANGAS DE NARCEA & 24.38 \\
\hline NE-001 & NEGRO & ASTURIAS & NEGRO & LUARCA & 23.88 \\
\hline MI-049 & LA FRAGUA & CASTILLA-LEÓN & MIÑO & VILLAGATON & 18.95 \\
\hline MI-060 & LA VEGA & CASTILLA-LEÓN & MIÑO & CANDIN & 15.78 \\
\hline MI-001 & SAN MARTIN & GALICIA & MIÑO & XERMADE & 15.57 \\
\hline LI-004 & VIDUEIRO & GALICIA & LIMIA & RAIRIZ DE VEIGA & 15.16 \\
\hline NE-002 & NEGRO & ASTURIAS & NEGRO & LUARCA & 15.07 \\
\hline MI-151 & TEA & GALICIA & MIÑO & COVELO (O) & 13.60 \\
\hline MI-061 & ANCARES & CASTILLA-LEÓN & MIÑO & CANDIN & 13.52 \\
\hline LI-002 & NOCELO & GALICIA & LIMIA & XINZO DE LIMIA & 13.17 \\
\hline NA-025 & MEIRO & ASTURIAS & NAVIA & COAÑA & 12.27 \\
\hline MI-088 & CONSO & GALICIA & MIÑO & VILARIÑO DE CONSO & 9.83 \\
\hline MI-003 & LADRA & GALICIA & MIÑO & VILLALBA & 9.56 \\
\hline MI-057 & CUA & CASTILLA-LEÓN & MIÑO & PERANZANES & 8.37 \\
\hline ES-003 & ESVA & ASTURIAS & ESVA & TINEO & 7.98 \\
\hline MI-087 & CAMBA & GALICIA & MIÑO & VIANA DO BOLO & 7.66 \\
\hline MI-132 & ARENTEIRO & GALICIA & MIÑO & CARBALLIÑO (O) & 7.42 \\
\hline MI-090 & REQUEJO & GALICIA & MIÑO & VEIGA (A) & 7.42 \\
\hline MI-050 & RIAL & CASTILLA-LEÓN & MIÑO & TORRE DEL BIERZO & 7.31 \\
\hline LI-007 & SALAS & GALICIA & LIMIA & MUIÑOS & 7.16 \\
\hline MI-119 & CINSA & GALICIA & MIÑO & MONFORTE DE LEMOS & 6.55 \\
\hline MI-147 & CIERVES & GALICIA & MIÑO & RIBADAVIA & 5.95 \\
\hline MI-089 & CONSO & GALICIA & MIÑO & VILARIÑO DE CONSO & 5.72 \\
\hline MI-133 & VIÑAO & GALICIA & MIÑO & IRIXO (O) & 5.50 \\
\hline NA-020 & VILLANUEVA & ASTURIAS & NAVIA & VILLANUEVA DE OSCOS & 5.15 \\
\hline
\end{tabular}


Table 2. Alphabetical list of the studied sites where the most relevant Eunotia species were identified (abundances higher than $5 \%$ in at least one sample), indicating the site code, the values of the environmental variables, the SPI value, and the relative abundance of each Eunotia species. For the Eunotia code see Table 3. Lista en orden alfabético de las localidades estudiadas donde las especies mas relevantes de Eunotia fueron identificadas (abundancias superior al $5 \%$ en al menos una muestra). Indicando el valor de las variables estudiadas, valor del IPS y la abundancia relativa de cada especie de Eunotia. Para saber el código Eunotia ver Tabla 3.

\begin{tabular}{|c|c|c|c|c|c|c|c|c|c|c|c|c|c|c|c|}
\hline CODE & $\begin{array}{l}\text { ALTITU. } \\
\text { (m) }\end{array}$ & $\begin{array}{c}\text { SLOPE } \\
(\%)\end{array}$ & $\begin{array}{c}\text { TEMP. } \\
\left({ }^{\circ} \mathbf{C}\right)\end{array}$ & $\begin{array}{c}\text { DIS. OXI. } \\
(\mathrm{mg} . / \mathrm{l})\end{array}$ & $\begin{array}{l}\text { COND. } \\
(\mu \mathrm{S} / \mathrm{cm})\end{array}$ & pH & SPI & EBIL & EEXI & EFOR & EIMP & EINC & EMIN & EPEC & ESUB \\
\hline EO-001 & 624 & 2.38 & 15.03 & 9.11 & 36.00 & 6.79 & 19.50 & - & - & - & 19.11 & - & 20.35 & - & - \\
\hline ES-003 & 298 & 2.94 & 18.15 & 8.22 & 35.00 & 4.70 & 18.90 & - & 0.44 & - & 1.11 & - & - & - & 6.43 \\
\hline LI-002 & 631 & 1.25 & 14.07 & 6.69 & 111.60 & 6.50 & 14.00 & - & - & 3.17 & 5.85 & - & 3.90 & - & - \\
\hline LI-004 & 638 & 0.87 & 12.94 & 7.70 & 58.70 & 6.77 & 17.50 & 1.47 & - & 1.22 & 8.80 & 0.49 & 1.71 & - & - \\
\hline LI-007 & 703 & 0.79 & 15.80 & 7.35 & 34.60 & 6.57 & 18.60 & - & 1.19 & - & 2.63 & 1.43 & 0.24 & - & 1.43 \\
\hline MI-001 & 457 & 0.62 & 14.47 & 9.88 & 42.00 & 6.37 & 18.50 & - & 2.43 & - & 8.76 & 4.38 & - & - & - \\
\hline MI-002 & 484 & 0.04 & 14.45 & 9.31 & 51.00 & 5.30 & 19.30 & - & - & - & 15.58 & 7.00 & 0.45 & - & - \\
\hline MI-003 & 424 & 0.23 & 14.21 & 8.62 & 61.00 & 5.56 & 17.90 & 0.25 & 0.49 & - & 4.66 & - & 0.49 & 3.68 & - \\
\hline MI-004 & 440 & 1.03 & 13.97 & 9.41 & 34.00 & 3.75 & 18.90 & - & - & - & - & - & 25.48 & - & 29.68 \\
\hline MI-005 & 419 & 0.33 & 14.84 & 8.06 & 46.00 & 6.73 & 18.70 & 6.68 & 3.10 & 5.73 & 1.91 & 4.77 & 6.68 & - & - \\
\hline MI-049 & 851 & 4.75 & 11.23 & 10.39 & 93.00 & 5.94 & 19.20 & - & 15.96 & - & 0.25 & 2.24 & 0.50 & - & - \\
\hline MI-050 & 783 & 2.74 & 13.60 & 9.23 & 40.00 & 6.47 & 15.70 & - & - & - & - & - & 7.31 & - & - \\
\hline MI-057 & 1075 & 2.32 & 12.00 & 9.98 & 11.20 & 5.57 & 19.40 & 1.40 & - & - & - & - & 5.58 & - & 1.40 \\
\hline MI-060 & 1086 & 3.71 & 11.60 & 10.04 & 17.60 & 6.21 & 19.50 & - & - & - & - & - & 12.38 & - & - \\
\hline MI-061 & 824 & 2.20 & 13.00 & 10.06 & 23.00 & 5.59 & 19.30 & - & 2.33 & - & - & - & 11.19 & - & - \\
\hline MI-078 & 409 & 1.83 & 15.00 & 9.24 & 518.00 & 4.36 & 19.30 & - & 69.70 & - & - & - & - & - & - \\
\hline MI-087 & 734 & 0.96 & 18.85 & 8.79 & 21.80 & 6.75 & 19.40 & - & 0.48 & 0.24 & 3.59 & 2.87 & 0.48 & - & - \\
\hline MI-088 & 1080 & 3.33 & 14.20 & 6.35 & 17.70 & 7.05 & 16.90 & - & - & - & 2.21 & - & 6.39 & - & - \\
\hline MI-089 & 708 & 3.33 & 15.25 & 7.90 & 22.50 & 6.46 & 17.30 & - & 0.23 & - & 1.37 & - & 4.12 & - & - \\
\hline MI-090 & 968 & 2.74 & 13.46 & 7.98 & 23.00 & 6.42 & 18.30 & - & 0.24 & - & 2.39 & - & 4.55 & - & - \\
\hline MI-117 & 481 & 2.71 & 14.42 & 9.46 & 39.00 & 6.68 & 19.50 & - & 1.89 & - & 34.99 & 1.18 & - & - & - \\
\hline MI-119 & 275 & 0.64 & 17.10 & 6.55 & 105.20 & 4.66 & 15.90 & 0.49 & 0.49 & 0.24 & 1.21 & 0.97 & 2.18 & - & - \\
\hline MI-132 & 396 & 0.15 & 14.24 & 8.49 & 30.20 & 6.22 & 15.90 & - & - & - & 6.55 & - & - & - & 0.87 \\
\hline MI-133 & 522 & 1.79 & 12.49 & 8.59 & 38.60 & 7.31 & 18.50 & - & - & - & 3.67 & - & - & - & 0.46 \\
\hline MI-138 & 531 & 0.51 & 15.48 & 8.07 & 28.70 & 5.95 & 17.50 & 7.21 & 1.86 & - & 16.51 & - & 2.33 & - & - \\
\hline MI-147 & 105 & 6.53 & 17.83 & 8.49 & 25.90 & 6.36 & 19.80 & - & - & - & 2.38 & - & - & - & - \\
\hline MI-151 & 475 & 9.67 & 16.39 & 8.79 & 19.30 & 6.26 & 19.80 & - & - & - & - & - & 10.02 & - & 0.95 \\
\hline MI-500 & 472 & 0.43 & 14.44 & 9.47 & 38.00 & 6.00 & 19.70 & 7.54 & 10.71 & 0.49 & 16.06 & 9.98 & - & - & 6.33 \\
\hline NA-020 & 534 & 2.52 & 14.20 & 9.04 & 50.60 & 5.78 & 18.40 & - & - & - & - & - & 5.15 & - & - \\
\hline NA-025 & 205 & 1.93 & 16.70 & 8.74 & 57.60 & 5.39 & 18.20 & - & 2.45 & - & - & - & - & 5.32 & - \\
\hline NA-027 & 665 & 3.89 & 13.11 & 9.83 & 16.00 & 5.82 & 19.20 & - & - & - & - & - & 24.38 & - & - \\
\hline NAL-029 & 572 & 3.06 & 13.13 & 9.35 & 27.00 & 6.75 & 16.70 & - & - & - & - & - & 24.38 & - & - \\
\hline NE-001 & 211 & 2.94 & 15.39 & 9.81 & 30.00 & 3.67 & 16.80 & - & - & - & - & - & 23.88 & - & - \\
\hline NE-002 & 25 & 1.00 & 17.14 & 8.05 & 44.00 & 5.36 & 18.70 & - & 2.74 & - & - & 4.34 & 7.99 & - & - \\
\hline
\end{tabular}


Table 3. Alphabetical list of the Eunotia taxa identified in the studied region, indicating the number of localities where they have been found and the number of the previous references for each one in the Iberian Peninsula and in the studied area. Lista en orden alfabético de los taxones de Eunotia identificados en la zona de estudio indicando el número de localidades donde se han encontrado y el número de citas previas para cada una en la península Ibérica y en el área de estudio.

\begin{tabular}{|c|c|c|c|c|}
\hline \multirow{2}{*}{ Taxon Code } & \multirow{2}{*}{ TAXON } & \multirow{2}{*}{ N. Sites } & \multicolumn{2}{|c|}{ N. References } \\
\hline & & & Iberian peninsula & Studied area \\
\hline EBIL & Eunotia bilunaris (Ehrenberg) Mills & 15 & 42 & 13 \\
\hline EBLI & Eunotia bilunaris var. linearis (Okuno) Lange-Bertalot \& Nörpel & 2 & 1 & 1 \\
\hline EBMU & Eunotia bilunaris var. mисорhila Lange-Bertalot \& Nörpel & 3 & 4 & 0 \\
\hline EEXI & Eunotia exigua (Brebisson ex Kützing) Rabenhorst & 22 & 22 & 5 \\
\hline EFOR & Eunotia formica Ehrenberg & 11 & 8 & 3 \\
\hline EIMP & Eunotia implicata Nörpel, Lange-Bertalot \& Alles & 59 & 2 & 2 \\
\hline EINC & Eunotia incisa Gregory & 21 & 10 & 1 \\
\hline EUIN & Eunotia intermedia (Krasske ex Hustedt) Nörpel \& Lange-Bertalot & 4 & 1 & 1 \\
\hline EMIN & Eunotia minor (Kützing) Grunow in Van Heurk & 69 & 23 & 4 \\
\hline EUPA & Eunotia paludosa Grunow & 1 & 1 & 0 \\
\hline EPEC & Eunotia pectinalis (Dillwyn, O.F. Müller, Kützing) Rabenhorst & 3 & 64 & 10 \\
\hline EPUN & Eunotia pectinalis var. undulata (Ralfs) Rabenhorst & 3 & 11 & 5 \\
\hline EPRA & Eunotia praerupta Ehrenberg & 1 & 17 & 5 \\
\hline ESOL & Eunotia soleirolii (Kützing) Rabenhorst & 1 & 1 & 0 \\
\hline ESUB & Eunotia subarcuatoides Alles, Nörpel \& Lange-Bertalot & 13 & 2 & 2 \\
\hline ETEN & Eunotia tenella (Grunow) Hustedt & 13 & 16 & 2 \\
\hline EVEN & Eunotia veneris (Kützing) De Toni & 1 & 5 & 1 \\
\hline
\end{tabular}

$\mathrm{pH}>$ 7. Diatoms with no apparent optimum in $\mathrm{pH}$ values are considered indifferent in this classification, nevertheless diatoms which are insensitive to $\mathrm{pH}$ are extremely rare, even diatoms which occur over a very wide $\mathrm{pH}$-range are rarely indifferent.

A principal component analysis (PCA) was performed to classify the sample stations according to their environmental variables (conductivity, altitude, water temperature, dissolved oxygen, slope, $\mathrm{pH}$, and pollution levels as assessed with the SPI diatom index). In order to relate the Eunotia species data to these environmental variables, a Canonical Correspondence Analysis (CCA) was carried out. Both the PCA and the CCA were computed with the MVSP version 3.13n software. Other physical and chemical characteristics of the sampled sites were not available for our sampling stations to improve the CCA and PCA analysis results. These analyses were carried out only in those samples where the most relevant Eunotia species were identified (abundances higher than $5 \%$ in at least one sample) (Table 2).

The maps were drawn using the ArcMap software (ESRI $®)$.

\section{RESULTS}

Up to 117 sites with Eunotia species were found (Fig. 1). However, only in 34 was their abundance higher than $5 \%$ (Table 1). Galicia, with 78 localities, was the region with higher representation, followed by Asturias with 21 and Castilla-León with 14; Cantabria and Navarra with 2 sites each and the Basque Country with none, are less represented regions. The basin with most occurrences of Eunotia species was Miño, followed by Navia, Nervión, and Limia. 
Up to 17 taxa were identified at a specific level in the studied area. The taxa identified have different occurrence and distribution; only 8 of the identified Eunotia species have abundances higher than $5 \%$ in at least one sample and 6 were found with abundances never higher than $1 \%$. Table 2 shows the most relevant Eunotia species identified (abundances higher than $5 \%$ in at least one sample) and figure 2 shows the distribution of the best represented Eunotia species in the studied area. All the species except $E$. soleirolii were previously reported in the floristic list of Aboal et al. (2003a). E. soleirolii was mentioned for the first time in Goma et al. (2004). The number of localities for each taxon and the number of its previous references in the Iberian Peninsula and in the studied area are showed in Table 3.
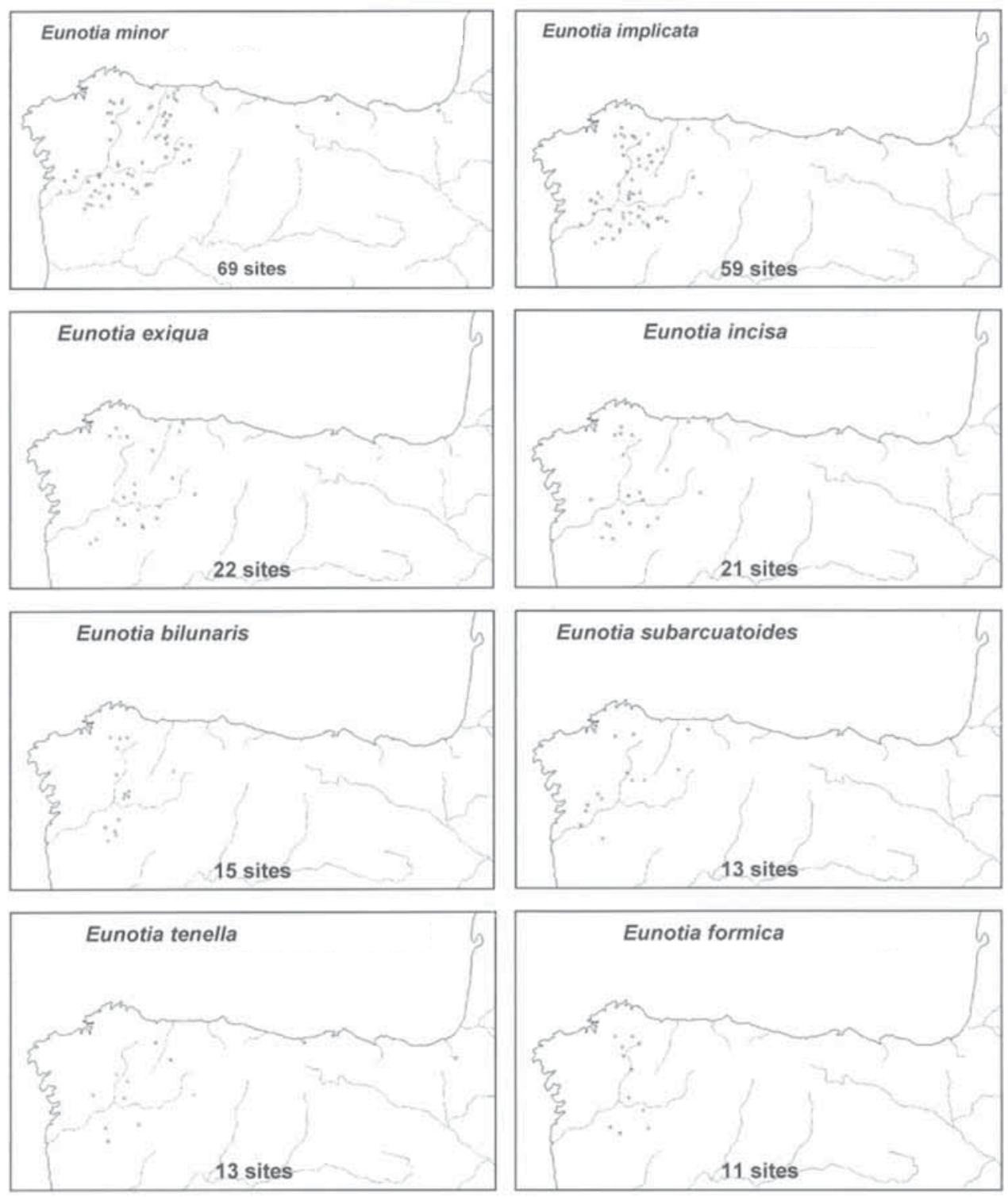

Figure 2. Distribution of the more frequent Eunotia (Bacillariophyceae) species in the studied basins. Distribución de las especies del género Eunotia (Bacillariophyceae) más frecuentes en las cuencas estudiadas. 


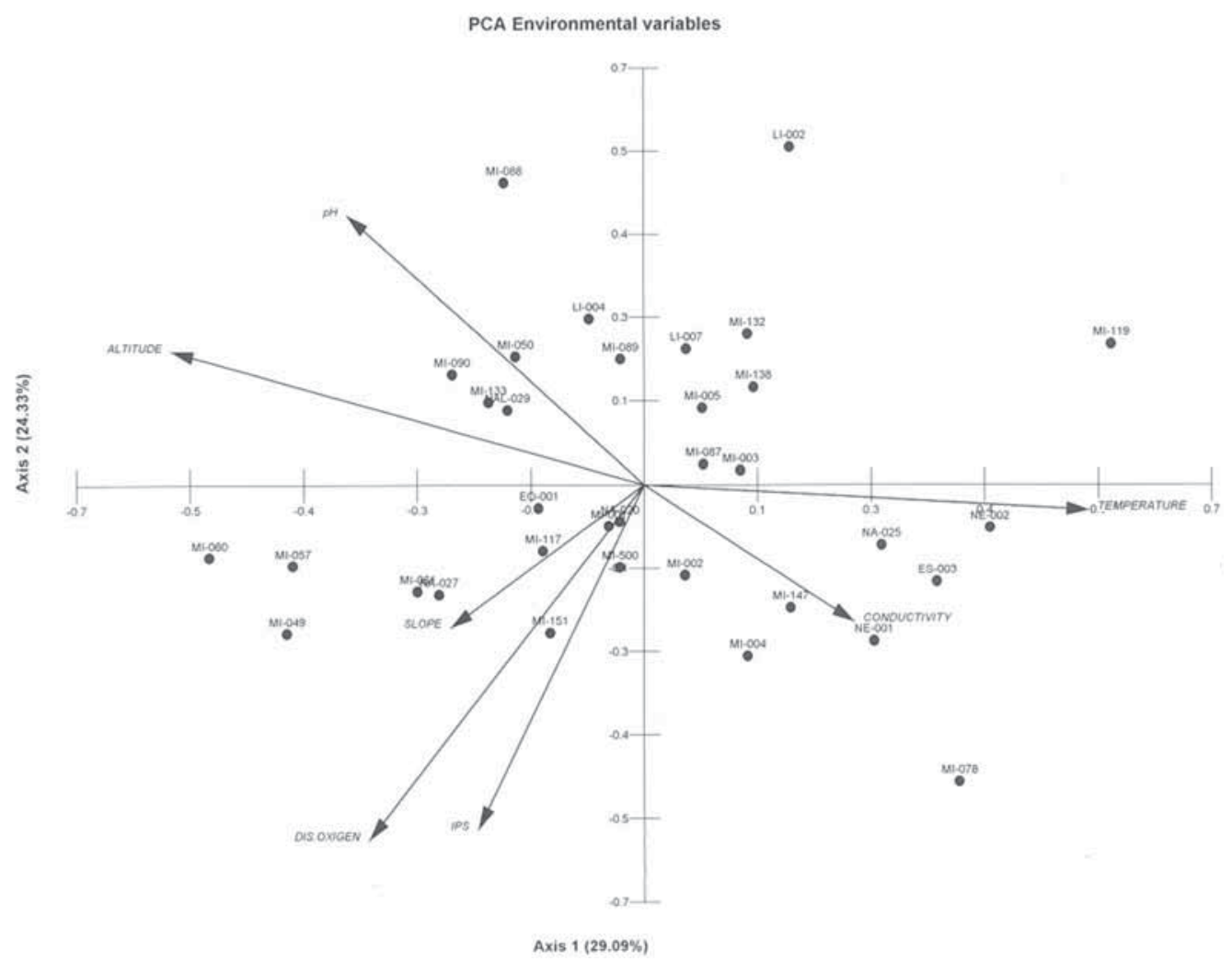

Figure 3. Results of the principal component analyses (PCA) of the environmental variables in the sites where the most relevant Eunotia species were identified (abundances higher than $5 \%$ in at least one sample). The percentage of variance explained by the PCA axes is indicated in brackets. Resultados del análisis de componente principales (ACP) de las variables ambientales en las localidades donde las especies de Eunotia más relevantes fueron identificadas (abundancias superiores al $5 \%$ en al menos una muestra). El porcentaje de varianza explicada por cada eje del ACP se indica entre paréntesis.

\section{Observations and descriptions}

Eunotia bilunaris (Ehrenberg) Mills 1934 (Fig. 3: A-B, Fig. 4: D)

Krammer \& Lange-Bertalot 1991, 180, Fig. 137, 139 (1-4); Metzeltin \& Witkowski 1996, 98, Fig. 33:14; Lange-Bertalot \& Metzeltin 1996, 136, Fig.9: 1-4

This species is characterized by the lunate appearance of its valve, the small terminal nodules and its indistinct raphe. It often produces abnormal forms which have the margins indented in several ways. These have been described as varieties. Striae: 13-18/10 $\mu \mathrm{m}$. Length: $20-150 \mu \mathrm{m}$. Breadth: 3-6 $\mu \mathrm{m}$. This species is widely distributed in waters with a low mineral content; commonly found in acid waters, but may occur in slightly alkaline waters (Patrick \& Reimer, 1966). Two optima in $\mathrm{pH}$ values which are almost equally developed, one around 4.0-4.3, the other one around or beyond pH 7 (Alles et al., 1991). This taxon has no apparent optimum in $\mathrm{pH}$ (Van Damm et al., 1994).

In the studied area, the species was collected in habitats with $\mathrm{pH}: 4.7-7.5$, conductivity: 11.2-132 $\mu \mathrm{S} / \mathrm{cm}$, altitude: $275-1075 \mathrm{~m}$ asl, SPI: 12.3-19.7. Its maximum abundance was between $6.7 \%-7.5 \%$ in the Miño basin with $\mathrm{pH}: 5.9-6.7$, conductivity $28.7-46 \mu \mathrm{S} / \mathrm{cm}$, altitude: $419-531 \mathrm{~m}$ asl, SPI: 17.5-19.7

Eunotia bilunaris var. linearis (Okuno) LangeBertalot \& Nörpel 1991

Krammer \& Lange-Bertalot, 1991, 180: Fig. 137: 13-16. 
Valves very slender, elongated with parallel margins, slightly bent to almost straight, often wavily-crooked, more or less capitately widened on the ends, half-circular rounded on the apical valve margin. Transapical striae dense and regular. Raphe in the valve surface with a stroke-shaped appendage, which begins on the raphe end and runs back proximally, parallel with the apical axis. Striae: 9-12/10 $\mu \mathrm{m}$. Length: 44-205 $\mu \mathrm{m}$. Breadth: 3.5-5.5 $\mu \mathrm{m}$. Acidophilus: mainly occurring at $\mathrm{pH}<7$ (Van Damm et al., 1994).

This taxon is not very well represented in this region, it was found only in two sites with an abundance $<0.5 \%$.

Eunotia bilunaris var. mucophila LangeBertalot \& Nörpel 1991

Krammer \& Lange-Bertalot, 1991, 180: Fig. 138: 20-24.

Cells in girdle view rectangular; laterally asymmetrical (lunate) in valve view along the apical axis. Valves bent, gradually narrowing towards rounded apices. Ventral margin concave and dorsal margin convex. Valves less arcuate in smallest individuals. Striae uniseriate, divergent

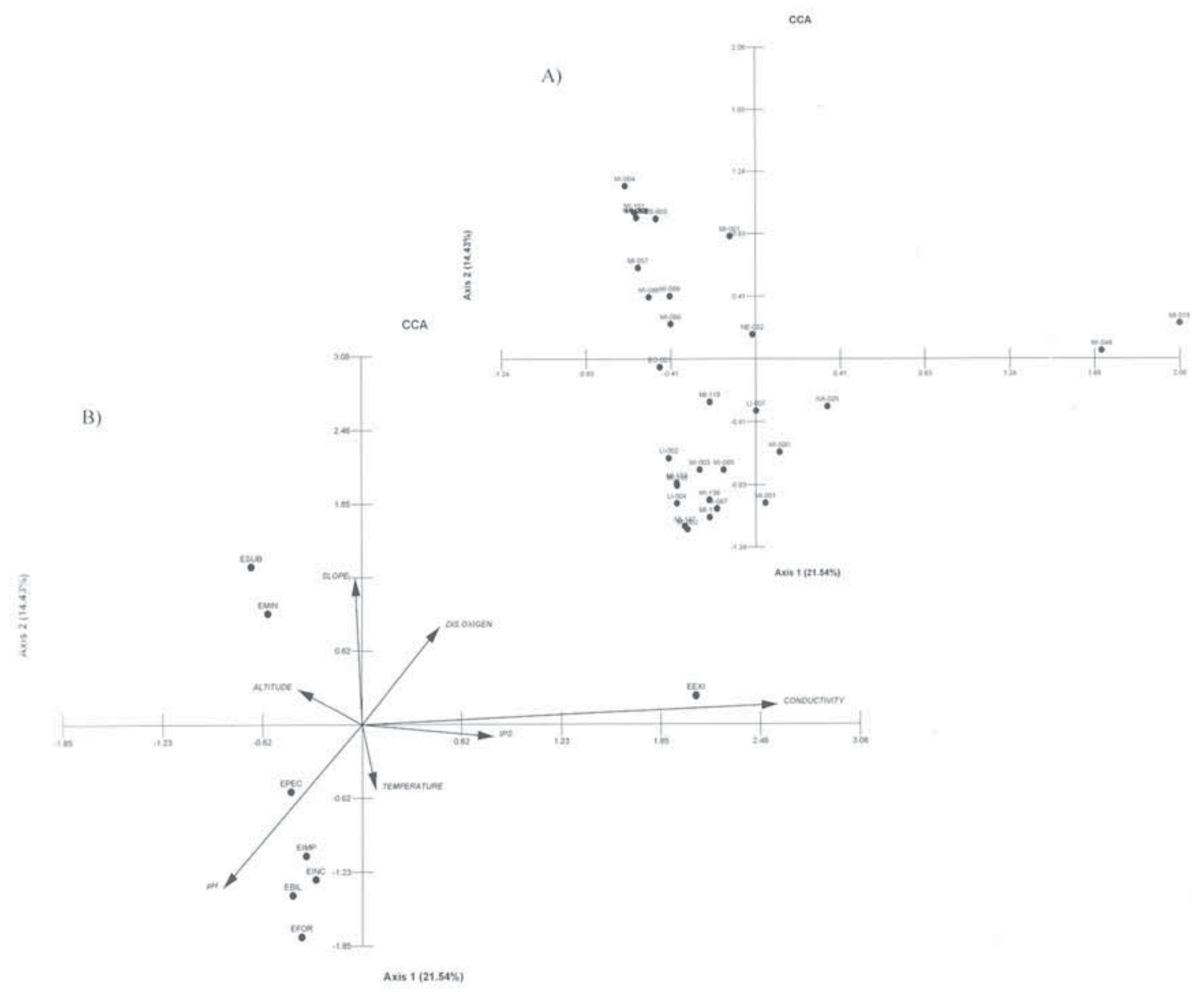

Figure 4. Results of a Canonical Correspondence Analysis (CCA) based on the most relevant Eunotia species (abundances higher than $5 \%$ in at least one sample) with respect to environmental variables. Sampled sites (A) and Eunotia species (B) (abbreviation codes are given in Table 3) are displayed on the CCA axis in separated plots. The percentage of variance explained by axis of the CCA is indicated in brackets. Resultados del análisis canónico de correspondencias (ACC) de las especies más relevantes de Eunotia (abundancias superiores al $5 \%$ en al menos una muestra) respecto a las variables ambientales. Las localidades (A) y las especies de Eunotia (B) (la abreviatura de los códigos están en la Tabla 3) están representados en ejes de ACC en gráficos separados. El porcentaje de varianza explicada por cada eje del ACC se indica entre paréntesis. 
from the ventral margin to the dorsal one. Striae: 20-28/10 $\mu \mathrm{m}$. Length: 10-70 $\mu \mathrm{m}$. Breadth: 1.9-2.7 $\mu \mathrm{m}$. Acidophilus: mainly occurring at $\mathrm{pH}<7$ (Van Damm et al., 1994).

This taxon is not very well represented in this region, it was found only in three sites with abundance lower than $0.5 \%$.

Eunotia exigua (Brébisson ex Kützing) Rabenhorst 1864 (Fig. 3: G-I, Fig. 4: E)

Krammer \& Lange-Bertalot 1991, 199, Fig. 153: 5-43; Hustedt 1957, 240; Hustedt 1959, 285 , Fig. 751: a-r; Schoeman 1973, 75; Patrick et al. 1975, 215, Fig. 13: 17-18; Patrick \& Reimer, 1966, 215, 13:17-18.

Ventral margin concave. Dorsal margin usually more strongly convex. Margins of the valve usually not parallel. Valve gradually broadened toward the centre. Dorsal margin strongly reflexed to form capitate, more or less truncate ends. Terminal nodules on ventral margin at the apices of the valve. Striae parallel, $20-25 / 10 \mu \mathrm{m}$. Length: 10-26 $\mu \mathrm{m}$. Breadth: 2-4 $\mu \mathrm{m}$. Often found associated with mosses in acid water of low mineral content (Patrick \& Reimer, 1966). This species tolerates high and abrupt variations of $\mathrm{pH}$ values (Alles et al., 1991). Acidobiontic: optimal occurrence at $\mathrm{pH}<5.5$ (Van Damm et al., 1994).

In the studied area the species was collected in habitats with $\mathrm{pH}: 4.4-7.4$, conductivity: 17.4-518 $\mu \mathrm{S} / \mathrm{cm}$, altitude: $25-968 \mathrm{~m}$ asl, SPI: 15.9-19.7. Its highest abundance is $69.7 \%$ in the river Cayoso (Miño basin) in Carballeda (Galicia) with $\mathrm{pH}: 4.4$, conductivity $518 \mu \mathrm{S} / \mathrm{cm}$, altitude: 409 m asl, SPI: 19.3.

Eunotia formica Ehrenberg 1843 (Fig. 3:T)

Krammer \& Lange-Bertalot 1991, 209, Fig. 152: 8-12A; Hustedt 1930, 186, Fig. 257; Hustedt 1957, 242; Hustedt 1959, 308, Fig. 775; Germain 1981, 90, Fig. 31: 29-31; Lange-Bertalot \& Metzeltin 1996, 144, Fig. 13: 1-2.

This species is easily recognized by its wedge-capitated ends and the swelling at the centre of the valve. Valve usually linear, sometimes slightly bent. Striae parallel, often not equidistant; in many cases broken near the ventral margin. Striae: 6-12/10 $\mu \mathrm{m}$. Length: (12)35200(300) $\mu \mathrm{m}$. Breadth: 7-14 $\mu \mathrm{m}$. It is typically found in acid to circumneutral soft waters, stan- ding or usually slow-flowing waters (Patrick \& Reimer 1966). Acidophilus: mainly occurring at $\mathrm{pH}<7$ (Van Damm et al., 1994).

In the studied area the species was collected in habitats with $\mathrm{pH}$ : 4.7-7.3, conductivity: $21.8-177 \mu \mathrm{S} / \mathrm{cm}$, altitude: $275-734 \mathrm{~m}$ asl, SPI: 14-19.7. Its highest abundance is $5.7 \%$ in river Tamoga (Miño basin) in Villalba (Galicia) with $\mathrm{pH}: 6.7$, conductivity $46 \mu \mathrm{S} / \mathrm{cm}$, altitude: $419 \mathrm{~m}$ asl, SPI: 18.7 .

Eunotia implicata Nörpel, Lange-Bertalot \& Alles 1991 (Fig. 3: C, Fig. 4: B, I)

Krammer \& Lange-Bertalot 1991, 197, Fig. 143: 1-9A, Fig. 144: 6.

Ventral margin slightly concave. Dorsal margin distinctly convex, often with two shallow ondulations. Valve somewhat narrower at the ends than at the centre. Apices of the valve rounded; slightly narrower but not distinctly set off from the main body of the valve. Terminal nodules near, but not at the ends of the valve; distinct but not large. Striae straight; almost perpendicular to ventral margin at the centre of the valve, but sometimes curved at the ends. Striae, usually $14-16 / 10 \mu \mathrm{m}$ at the centre, to about 22 in $10 \mu \mathrm{m}$ at the ends. Length: 20-40 $\mu \mathrm{m}$. Breadth: 3-6 $\mu \mathrm{m}$. Acidophilus: mainly occurring at $\mathrm{pH}<7$ (Van Damm et al., 1994).

In the studied area the species was collected in habitats with $\mathrm{pH}$ : 4.3-7.9, conductivity: $4.17-720 \mu \mathrm{S} / \mathrm{cm}$, altitude: $76-1356 \mathrm{~m}$ asl, SPI: 12.3-20. Its highest abundance is between $15.6 \%-35 \%$ in conditions with $\mathrm{pH}$ : 5.3-6.8, conductivity $28.7-51 \mu \mathrm{S} / \mathrm{cm}$, altitude: $472-624 \mathrm{~m}$ asl, SPI: 19.3-19.7.

Eunotia incisa Gregory 1854 (Fig. 3: O-R, Fig. 4: $\mathrm{C}, \mathrm{K})$

Krammer \& Lange-Bertalot 1991, 221, Fig. 161: 8-19, Fig. 162: 1-2, Fig. 163: 1-7; Metzeltin \& Witkowski 1996, 100, Fig.34:1; LangeBertalot \& Metzeltin 1996, 150, Fig. 8-15.

This species is characterized by the apices of the valve undifferentiated from the main body of the valve and by the very fine striae. Frustules in girdle view rectilinear. Frustules in valve view with straight ventral margin and convex dorsal margin. Apices of the valve usually acute, sometimes rounded. Striae more 

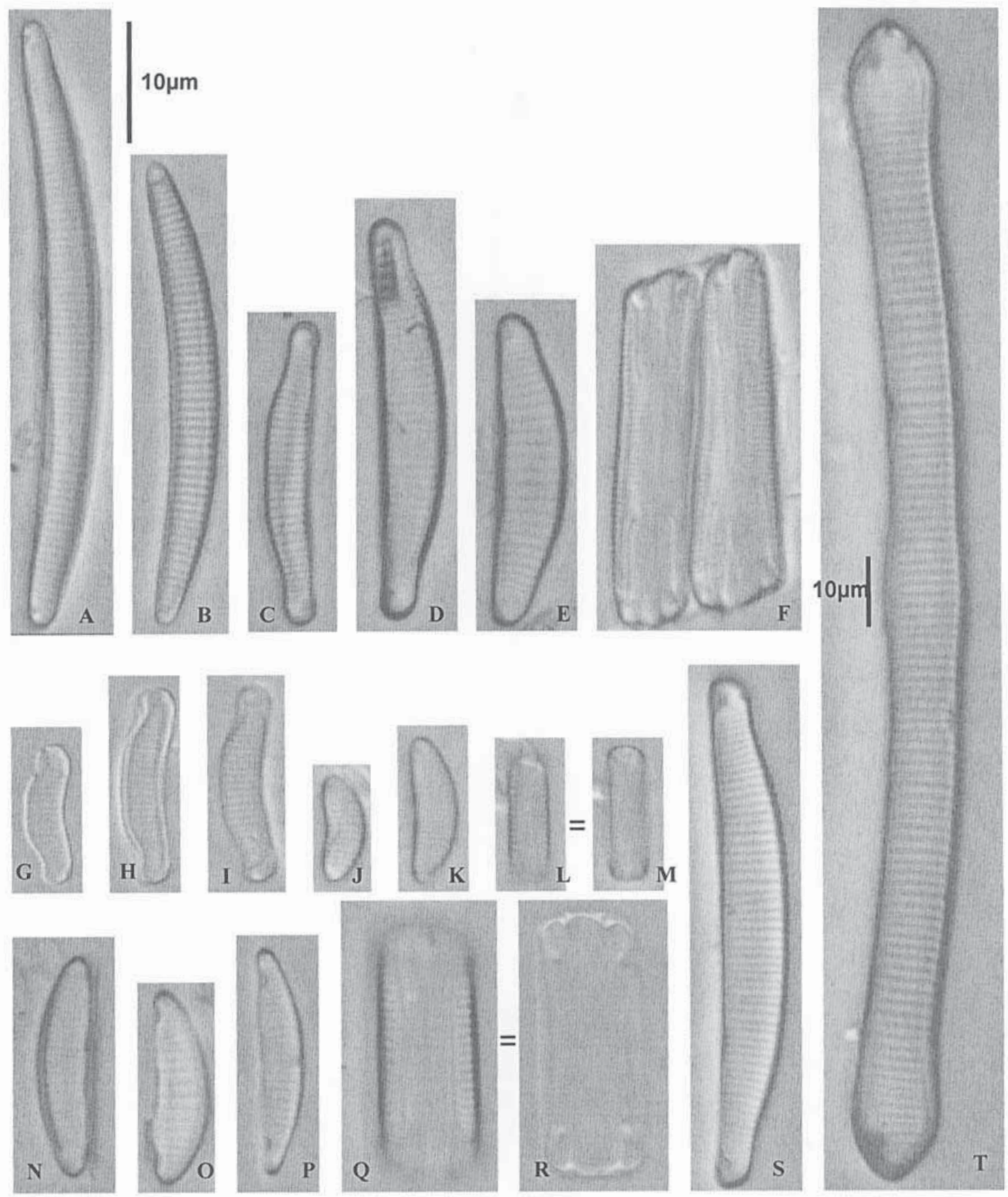

Figure 5. A-B: Eunotia bilunaris; C: Eunotia implicata; D-F: Eunotia minor; G-I: Eunotia euxigua; J-M: Eunotia subarcuatoides; N: Eunotia intermedia; O-R: Eunotia incisa; S: Eunotia cf. veneris; T: Eunotia formica. A-E, G-K, N-P; S-T: External valve view; F, L-M, Q-R: Frustule in girdle view, detail of girdle bands. A-E, G-R, N-P; S-T: vista externa de la valva; F, L-M, Q-R: Vista lateral del frústulo, detalle de las bandas interpleurales. 
distant at the centre of the valve than at the ends, 13-17/10 $\mu \mathrm{m}$. Length: 15-50 $\mu \mathrm{m}$. Breadth: 4-7 $\mu \mathrm{m}$. Acidophilus: mainly occurring at $\mathrm{pH}<7$ (Van Damm et al., 1994).

In the studied area the species was collected in habitats with $\mathrm{pH}$ : 4.7-6.8, conductivity: 4.17-194 $\mu \mathrm{S} / \mathrm{cm}$, altitude: $25-975 \mathrm{~m}$ asl, SPI: 15.5-19.8. Its highest abundance is between $7 \%-10 \%$ in conditions with $\mathrm{pH}$ : 5.3-6, conductivity $38-51 \mu \mathrm{S} / \mathrm{cm}$, altitude: $472-484 \mathrm{~m}$ asl, SPI: 19.3-19.7.

Eunotia intermedia (Krasske ex Hustedt) Nörpel \& Lange-Bertalot 1991 (Fig. 5: N)

Krammer \& Lange-Bertalot 1991, 215, Fig. 143: 10-15.

Ventral margin straight, wall thickened in areas halfway between the centre of the valve and the ends. Dorsal margin convex. Ends not distinctly formed, but confluent with the rest of the valve. Terminal nodules distinct, near the ends of the valve. Striae parallel, 14-16/10 $\mu \mathrm{m}$ at the centre of the valve, more numerous toward the ends. Length: $14-45 \mu \mathrm{m}$. Breadth: $3.5-5 \mu \mathrm{m}$. Acidophilus: mainly occurring at $\mathrm{pH}<7$ (Van Damm et al., 1994).

In the studied area the species was collected in habitats with $\mathrm{pH}$ : 5.4-7.3, conductivity: 17.6-112 $\mu \mathrm{S} / \mathrm{cm}$, altitude: $205-1086 \mathrm{~m}$ asl, SPI: 18.2-19.8 with abundance never higher than $3.4 \%$.

Eunotia minor (Kützing) Grunow in van Heurck 1881 (Fig. 3: D-F, Fig. 4: A, J)

Krammer \& Lange-Bertalot 1991, 196, Fig. 142: 7-15, Fig. 144: 5; Lange-Bertalot \& Metzeltin 1996, 144, Fig. 13: 18-21, Fig. 103:11.

Cells in girdle view thick, rectangular; laterally asymmetrical (lunate) in valve view along the apical axis. Valves bent with subrostrate large round apices. Ventral margin slightly concave but slightly inflated at the centre; dorsal margin convex. Striae uniseriate, on the ventral mantle more numerous and alternating, 9-15/10 $\mu \mathrm{m}$. Length: 20-60 $\mu \mathrm{m}$. Breadth: 4.5-8 $\mu \mathrm{m}$. Optimal abundance around pH 7 (Alles et al., 1991). Acidophilus: mainly occurring at $\mathrm{pH}<7$ (Van Damm et al., 1994).

In the studied area the species was collected in habitats with $\mathrm{pH}$ : 3.7-8.6, conductivity: 4.17-544 $\mu \mathrm{S} / \mathrm{cm}$, altitude: 14-1295 m asl,
SPI: 12.3-19.9. Its maxim abundance is between 10-25.5\% in conditions with $\mathrm{pH}$ : 3.8-6.8, conductivity $19.3-36 \mu \mathrm{S} / \mathrm{cm}$, altitude: $211-1086 \mathrm{~m}$ asl, SPI: 16.7-19.8.

Eunotia paludosa Grunow 1862 Krammer \& Lange-Bertalot 1991, 203, Fig. 155: 1-20, 22-37; Hustedt 1930, 178, Fig. 228; Grunow 1862, 336, Fig. 6: 10; Lange-Bertalot \& Metzeltin 1996, 152, Fig. 17: 48-19, Fig. 103:12.

Valve slightly arcuate, ventral and dorsal sides parallel, ends subcapitated. Striae parallel along the valve face, radial at one pole. Raphe oblique at the valve face, raphe endings slightly expanded. Girdle bands with several rows of poroids. Striae: 19-25/10 $\mu \mathrm{m}$. Length: 6-60 $\mu \mathrm{m}$. Breadth: 2-3(4) $\mu \mathrm{m}$. Often associated to mosses in acid waters of low mineral content, also in bogs and small streams (Patrick \& Reimer, 1966). Acidobiontic: optimal occurrence at $\mathrm{pH}<5.5$ (Van Damm et al., 1994).

One single occurrence in the Meiro River (Navia basin) in Coaña (Asturias).

Eunotia pectinalis (Dillwyn?,O. F. Müller?, Kützing) Rabenhorst 1864 (Fig. 6 H)

Krammer \& Lange-Bertalot 1991, 193, Fig. 141: 1-7, Fig. 143: 1; Metzeltin \& Witkowski 1996, 98, Fig. 33:1; Lange-Bertalot \& Metzeltin 1996, 146, Fig. 14: 5-7.

This is quite a variable taxon whose morphological variability is well documented (Geitler, 1932; Steinman \& Sheath, 1984). The varieties which are recognized represent the extremes of series of variations from the typical form. Rabenhorst gives Dillwyn as the authority for this specific name. However, Dilwyn names Müller as the authority in his citation of this name. It is impossible to be sure from the original description and plates that either Müller or Dillwyn actually were working with this taxon. Frustules rectangular in girdle view. Valve elongate, slightly curved or bent. Ventral margin straight or slightly concave, sometimes slightly swollen at the centre of the valve. Valve narrowed toward broadly attenuated, truncate rounded ends. Striae parallel slightly radiate at the ends. Striae: $7-12 / 10 \mu \mathrm{m}$ at the centre of the valve, to 14 in $10 \mu \mathrm{m}$ at the ends of the valve. Length: $17-140 \mu \mathrm{m}$. Breadth: 5-10 $\mu \mathrm{m}$. Acidophilus: mainly occurring at $\mathrm{pH}<7$ (Van Damm et al., 1994). 

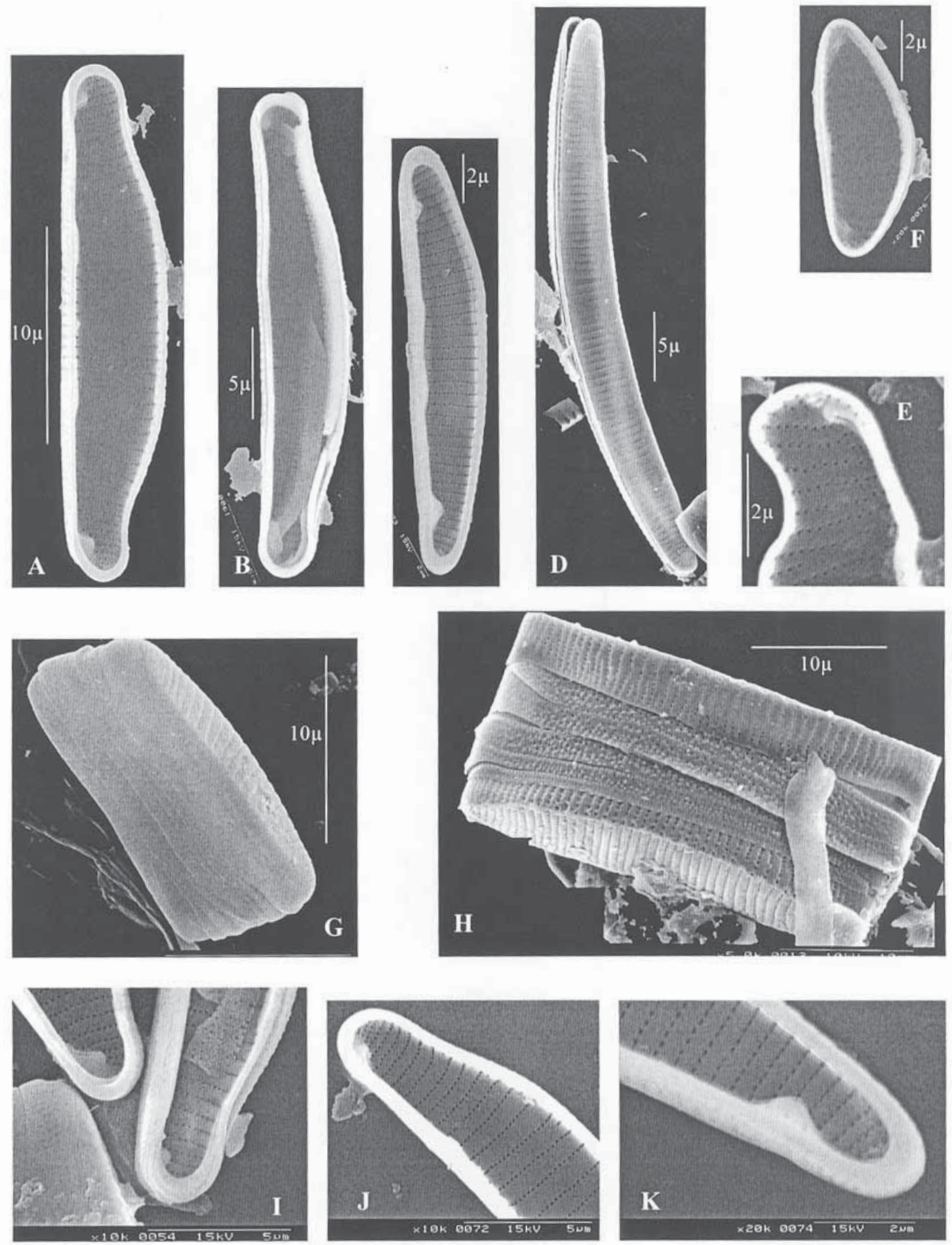

Figure 6. A, J: Eunotia minor; B, I: Eunotia implicata; C, K: Eunotia incisa; D: Eunotia bilunaris; E: Eunotia exigua; F-G: Eunotia subarcuatoides; H: Eunotia pectinalis. A-C, G-H: Internal view K-M: Internal view, detail of rimoportula and striae; D: External valve view; G-H: Frustule in girdle view, detail of girdle bands. A-C, G-H: Vista interna $\mathrm{K}-\mathrm{M}$ : Vista interna, detalle de la rimoportula y las estrias; D: Vista de la valva externa; G-H: Frústulo en vista lateral, detalle de las bandas interpleurales. 
In the studied area the species was collected in habitats with $\mathrm{pH}$ : 5.4-6.02, conductivity: 52-61 $\mu$ S/cm, altitude: $205-444 \mathrm{~m}$ asl, SPI: $17.7-$ 18.2 with abundance never higher than $5.3 \%$.

Eunotia pectinalis var. undulata (Ralfs) Rabenhorst 1864

Hustedt 1930, 182, Fig. 240; Hustedt 1959, 298, Fig. 763: i; Hustedt 1957, 241; Hustedt 1981, 98, Fig. 35: 3-11; Fig. 37: 1-4; Schoeman 1973, 78; Patrick \& Reimer 1966, 206, Fig. 12: 11; Krammer \& Lange-Bertalot 1991, 193, Fig. 141: 1-5.

This variety is easily distinguished by the many undulations, three or more, of the dorsal margin and the central swelling of the ventral margin. It is quite variable in outline. This variety prefers circumneutral waters of low mineral content (Patrick \& Reimer 1966). Acidophilus: mainly occurring at $\mathrm{pH}<7$ (Van Dammetal., 1994).

This taxon is not very well represented in this region, it was found only in three sites with abundance never higher than $0.5 \%$.

Eunotia praerupta Ehrenberg 1843 sensu lato

Krammer \& Lange-Bertalot 1991, 186, Fig. 148, 149: 1-7; Van Heurck 1880-1885, 143, Fig. 34: 19; Okuno 1974, 11, Fig. 845-846; Hustedt 1930, 174, Fig. 211; Hustedt 1957, 239; Hustedt 1959, 280, Fig. 747 A: a-e; Germain 1981, 88, Fig. 30: 7-8; Schoeman 1973, 81; Ehrlich 1995, 49, Fig. 8: 12-13; Metzeltin \& Witkowski 1996, 98, Fig. 33:6; Lange-Bertalot \& Metzeltin 1996, 142, Fig. 12: 12-13; Patrick \& Reimer 1966, 193, Fig. 10: 14.

This species can be easily recognized by the convexity of the dorsal margin and by the characteristic truncate-rostrate to slightly capitate ends. Frustules in girdle view, rectangular. Ventral margin usually slightly concave at the centre, straight at the ends of the valve; sometimes almost straight throughout the entire length. Striae parallel: 6-13/10 $\mu \mathrm{m}$. Length: 20-100 $\mu \mathrm{m}$. Breadth: 4-15 $\mu \mathrm{m}$. Usually in northern or mountainous localities in acid to circumneutral waters (Patrick \& Reimer, 1966). Acidophilus: mainly occurring at $\mathrm{pH}<7$ (Van Damm et al., 1994).

One single occurrence in Tremor River (Miño basin) in Torre del Bierzo (Castilla-León).

Eunotia soleirolii (Kützing) Rabenhorst 1864

Krammer \& Lange-Bertalot 1991, 194, Fig. 142:1, 2-6; Patrick \& Reimer 1966, 208, Fig. 13: 1-2.
The diagnostic character is the internal septation which seem to be a result of an abnormal division of the frustule. Valve linear-lunate in shape. The dorsal and ventral margins are parallel. Ends not differentiated clearly from the main part of the valve. It forms filaments in which the frustules contain internal septae. Striae: 12-14/10 $\mu \mathrm{m}$. Length: 30-65 $\mu \mathrm{m}$. Breadth: 3-4 $\mu \mathrm{m}$. Occurs predominantly in periodic water-bodies as well as under alkaline or acidic conditions, high or low electrolyte content (Patrick \& Reimer, 1966). Circumneutral: mainly occurring at $\mathrm{pH}$ values about 7 (Van Damm et al., 1994).

One single occurrence in Meiro River (Navia basin) in Coaña (Asturias).

Eunotia subarcuatoides E. Alles, M. Nörpel \& Lange-Bertalot 1991 (Fig. 3 : J-M, Fig. 4 : F-G) Krammer \& Lange-Bertalot 1991, 214, Fig. 138: 1-9, Fig. 145:6. Alles et al. 1991, 188, Fig. 4: 1-36.

Narrow linear in girdle view. Valves slender, bow-shaped, as a rule strongly curved, with more or less parallel margins. The dorsal line somewhat strongly sloping toward the ends, valves therefore slightly narrowed towards the end; ends rounded. End nodules small, raphe slightly developed. Small forms, rarely over $30 \mu \mathrm{m}$ long, strongly narrowed near the ends. Valves therefore strongly lanceolate, often only weakly bent. Striae: $18-23 / 10 \mu \mathrm{m}$. Length: 6-35(40) $\mu \mathrm{m}$. Breadth: 2.7-4.5 $\mu \mathrm{m}$. This species tolerate high and strong variations of $\mathrm{pH}-$ values (Alles et al., 1991). Acidobiontic: optimal occurrence at $\mathrm{pH}<5.5$ (Van Damm et al., 1994).

In the studied area the species was collected in habitats with $\mathrm{pH}$ : 3.8-7.7, conductivity: 11.2-720 $\mu \mathrm{S} / \mathrm{cm}$, altitude: $76-1075 \mathrm{~m}$ asl, SPI: 14-19.9. Its highest abundance was $29.7 \%$ in Tamoga river (Miño basin) in Abadin (Galicia) with $\mathrm{pH}: 3.8$, conductivity $34 \mu \mathrm{S} / \mathrm{cm}$, altitude: $440 \mathrm{~m}$ asl, SPI: 18.9 .

Eunotia tenella (Grunow) Hustedt in A. Schmidt et al. 1913

Krammer \& Lange-Bertalot 1991, 202, Fig. 154: 23-30; Hustedt 1930, 175, Fig. 220; Hustedt 1957, 240; Hustedt 1959, 284, Fig. 749; Germain 1981, 90, Fig. 31: 1-7, 22-26.

This species is characterized by its distinct terminal nodules on the ventral margin close 
to the apices. Ventral margin slightly concave. Dorsal margin narrows toward rostrate, rounded or somewhat capitated ends and varies in its degree of convexity. Margins sometimes almost parallel or swollen in the middle portion. Striae: $14-16 / 10 \mu \mathrm{m}$ at the centre to 20 in $10 \mu \mathrm{m}$ at the ends. Length: 6-37 $\mu \mathrm{m}$. Breadth: 2-4 $\mu \mathrm{m}$. Acidophilous: mainly occurring at $\mathrm{pH}<7$ (Van Damm et al., 1994).

In the studied area the species was collected in habitats with $\mathrm{pH}: 3.8-7.9$, conductivity: $16-632 \mu \mathrm{S} / \mathrm{cm}$, altitude: $250-1080 \mathrm{~m}$ asl, SPI: $14-19.9$. Its maxim abundance is $3 \%$ with $\mathrm{pH}: 6.8$, conductivity: $36 \mu \mathrm{S} / \mathrm{cm}$, altitude: $624 \mathrm{~m}$ asl, SPI: 19.5 .

Eunotia veneris (Kützing) De Toni 1892 (Fig. 3: S)

Krammer \& Lange-Bertalot 1991, 222, Fig. 163: 14-19.

Rectangular plate-shaped in girdle view, commonly shifted into rhombic shape. Valves half-lanceolate with straight ventral margin and symmetrically shallow, convex dorsal margin. Dorsal line bow-shaped; imperceptibly or not at all depressed near the ends. Ends quite sharply rounded. End nodules shifted proximally on the ventral line. Transapical striae $13-15 / 10 \mu \mathrm{m}$ in the middle, closer near the apices. Length: 15-50 $\mu \mathrm{m}$. Breadth: 4-6 $\mu \mathrm{m}$. Acidophilus: mainly occurring at $\mathrm{pH}<7$ (Van Damm et al., 1994).

One single occurrence in the river Cares (Deva-Cares basin) in Cabrales (Asturias).

\section{Environmental variables}

The sites where we found Eunotia species are characterised by low to neutral $\mathrm{pH}$. These optimal occurrences are according to van Damm et al. (1994) classification: species acidobiontic (optimal occurrence at ph $<5.5$ ): Eunotia exigua, $\mathrm{pH}: 4.36$, abundance: $69.70 \%$; E. subarcuatoides, $\mathrm{pH}$ : 3.75 , abundance: $29.68 \%$, and species acidophilous (mainly occurring at $\mathrm{pH}<7$ ): E. implicata $\mathrm{pH}$ : 6, abundance: $16.06 \%$; E. minor $\mathrm{pH}: 6.75$, abundance: $24.38 \%$.

A principal component analysis was carried out on the obtained environmental variables results to establish the environmental characteristics in those sites where the most relevant $\mathrm{Eu}$ - notia species were identified (abundances higher than $5 \%$ in at least one sample) (Table 2). Figure 5 shows the distribution of the variables in the space formed by the first two components, which explain a total of $53.41 \%$ of variance. The first component (29.09\% of variance) is determined by altitude and also, with a negative correlation, by $\mathrm{pH}$, dissolved oxygen, and slope. Other variables like temperature and conductivity are positively correlated to this component. The antagonism and extreme position of temperature and altitude along this axis was to be expected, the water temperature is lowered when altitude above sea level increases. The opposed position between conductivity and altitude along this axis could be interpreted in relation to the fact that in the upper stretches of the river, the rainfall is greater and the salt content lower. Dissolved oxygen and slope correlate with altitude. Taking into account these environmental variable correlations, the first component ordered the stations according to an altitudinal sequence and corresponds to an increase in water temperature and mineralization on the opposite direction.

The second axis (24.33\% of the variance) may be characterized by the parameters which determined the biological quality of water. Globally we observed that the highest notes of SPI (meaning very good quality) correspond to sites that were situated on the down site of the diagram. In those localities, we observed that a good oxygen dissolution rate combined with high slope provides a high self-purification power to the river and could explain the high SPI notes obtained. Rivers with moderate to null slopes are very sensitive to eutrophication and show much lower valves in the SPI diatom index (Tison et al., 2007). Therefore, this axis is related to the pollution levels of the studied area.

The Canonical Correspondence Analysis (CCA) allowed relating the most relevant $E u$ notia species identified (abundances higher than $5 \%$ in at least one sample) to the environmental parameters (Fig. 6). The first two axes explained $35.96 \%$ of the variance. The first axis $(21.54 \%$ of variance explained) was strongly correlated with conductivity; thereby the species were sorted along this axis following a water salinity gra- 
dient. The species which showed a highly positive correlation with this variable was Eunotia exigua with a clear tendency for waters with a certain mineral content. The other Eunotia species, with a poorly mineralized water preference, were grouped on the left side of the diagram. The second axis (14.43\% of variable explained) was positively correlated with dissolved oxygen and slope. Another important factor in the analysis was $\mathrm{pH}$, and was important on both axes; the CCA analysis revealed a strong positive influence on some Eunotia species such as Eunotia subarcuatoides and E. minor. The altitude and the water temperature had no clear influence on the $E u$ notia species distribution.

\section{SUMARY AND CONCLUSIONS}

Although Eunotia species occurred in $30 \%$ of the samples studied, only in $8.8 \%$ of the sites was their abundance over $5 \%$. The analysis of the samples showed that the genus Eunotia is well represented in the Galicia region. The basin with more occurrences of Eunotia species was Miño, followed by Navia, Nervión, and Limia. Eunotia minor and Eunotia implicata were the most geographically frequent species, occurring in $59 \%$ and $50.4 \%$ of the samples respectively. All of the taxa were previously mentioned in the floristic list of Aboal et al. (2003a) except $E$. soleirolii, which was cited for the first time in Goma et al. (2004). The lack of Eunotia species identification in the Basque Country can be due to the few sampling stations in this zone (the $4.5 \%$ in the whole studied area) and the neutral to alkaline $\mathrm{pH}$ values of these stations as well.

The localities where we found species of Eunotia are characterized by low to neutral $\mathrm{pH}$ and moderate conductivity, sometimes with extremely low values. The ecological characteristics given in the literature for the majority of the studied taxa agree with our observations except for $E$. minor which shows a large range of variability in $\mathrm{pH}$ values that is rather wider than those mentioned in van Damm et al. (1994) and Alles et al. (1991).

The distribution of Eunotia species in the studied area was related to some dominant environ- mental factors. As suggested by the results of the CCA, derived from Eunotia data analyses, these were conductivity and $\mathrm{pH}$. However, other factors affect Eunotia species presence in some rivers and streams in the studied area such as slope, dissolved oxygen and pollution levels. However, the altitude and the water temperature have no clear influence. Among the sets of these environmental parameters, conductivity plays the most important role, showing a high influence on $E u$ notia exigua. The $\mathrm{pH}$ had effects on the distribution of Eunotia species, the species were ordinated mainly along the second axis following an acidity gradient where Eunotia subarcuatoides and E. minor, in the upper side of the diagram, showed a clear preference for acidic waters. Altitude, based on the CCA analysis, contributes poorly to the prediction of Eunotia species in the studied area. In reality, hydro-morphological characteristics such as slope or dissolved oxygen values discriminate more than altitude. On the other hand, altitude was related to temperature variation but had minor influence on Eunotia species presence compared to pollution (assessed by SPI diatom index) and mineral content (assessed by conductivity).

According to the values obtained with the SPI diatom index, all the sampling sites had good or very good biological quality, so the anthropogenic pressure in the studied area is low. In agreement with this, a great deal of these localities could be close to reference conditions and so, we can consider that their $\mathrm{pH}$ value is highly linked to geology (Meybeck, 1986).

\section{ACKNOWLEDGEMENTS}

This project has been funded by the North Hydrographical Confederation of Spain $(\mathrm{CHN})$ and supported by the Spanish Science and Technology Ministry (Ministerio de Ciencia y Tecnología: Flora Ibérica de las algas continentales, REN2002-04397-C03-02).

We thank Christophe Bouillon for technical assistance; Viola Huck for its contribution in counting samples and both Olivier Monnier and, especially, Luc Ector for reviewing identifica- 
tions; Nuria Flor-Arnau and Esteve Llop for their support in statistics. The authors are also grateful to the Gabriel Lippmann Public Research Center and the Confederación Hidrográfica del Norte.

\section{REFERENCES}

ABOAL, M., M. ÁlVAREZ-COBELAS, J. CAMBRA \& L. ECTOR. 2003a. Floristic list of nonmarine diatoms (Bacillariophyceae) of Iberian Peninsula, Balearic Islands, and Canary Islands. Updated taxonomy and bibliography. Diatom Monograph, 4: 1-639.

ABOAL M., J. P. MARÍN y E. ZAFRA 2003b. Control de calidad biológica de los ríos de Euskadi mediante el uso de microalgas. La aplicación del índice Biológico de Diatomeas (IBD) en las Cuencas de Euskadi. Informe final. AMBIOTEK S.L. 126 pp.

ALLES, E., M. NÖRPEL-SCHEMPP \& H. LANGEBERTALOT. 1991. Zur Systematik und ökologie charakteristischer Eunotia-Arten (Bacillariophyceae) in elektrolytarmen Bachoberlaufen. Nova Hedwigia, 53: 171-213.

ALMEIDA, S. F. P. 2001. Use of diatoms for freshwater quality evaluation in Portugal. Limnetica, 20(2): 205-213.

ALONSO-FERNÁNDEZ, J. R. 1989. Estudio de las algas de agua dulce de los ríos asturianos y su utilización en la determinación de la calidad de sus aguas. Tesis Doctoral, Universidad de Oviedo. $689 \mathrm{pp}$.

ANTELO, J. M. 1991. Calidad de las aguas de la cuenca del río Barbaña. Efecto del Polígono Industrial de San Ciprian de Viñas. Fundación Empresa Universidad Gallega (FEUGA). Instituto Orensano de Desarrollo Económico (INORDE). Conselería de Industria e Comercio. Xunta de Galicia. 110 pp.

CAMERON, N. G. 1995. The representation of diatom communities by fossil assemblages in a small acid lake. J. Paleolimnol., 14: 185-223.

CARTER, J. R. \& R. J. FLOWER. 1988. A new species of Eunotia, E. pirla sp. nov., from Woolmer pond, an acid pool in the Southeast of England. Diatom Research, 3(1): 1-8.

CEMAGREF. 1982. Étude des methodes biologiques d'appréciation quantitative de la qualité des eaux. Rapport Division qualité des eaux Cemargref Lyon. Agence de l'eau Rhône-MéditerranéeCorse. 218 pp.

COSTE, M. et M. RICARD. 1982. Contribution a l'étude des diatomées d'eau douce des Seychelles et de l'Ile Maurice. Cryptogamie: Algologie, III, 4: 279-313.

DESCY, J. P. 1979. A new approach to water quality estimation using diatoms. Nova Hedwigia, 64: 305-323.

DESCY, J. P. \& M. COSTE. 1991. A test of methods for assessing water quality based on diatoms. Verh. Internat. Verein Limnol., 24: 2112-2116.

DÍAZ-CASTRO, J. G., R. M. SOUZA-MOSIMANN DE, R. LAUDARES-SILVA e B. R. FORSBERG. 2003. Composição da comunidade de diatomáceas perifíticas do rio Jaú, Amazona, Brasil. Acta Amazonica, 33(4): 583-606.

ECTOR, L., J. SANTAMARÍA-FERNÁNDEZ y M. T. GARCÍA-BERNADAL. 1992. Cartografía de la calidad biológica de las aguas de los ríos de la vertiente atlántica de Galicia Costa. Universidad de Santiago de Compostela. Consellería de Ordenación de Territorio e Obras Públicas. Xunta de Galicia. 110 pp.

EHRLICH, A. 1995. Atlas of the Inland Water Diatom Flora of Israel. Flora Palestina. The Geological Survey of Israel. The Israel Academy of Sciences and Humanities.

EUROPEAN COMMITTEE FOR STANDARIZATION. 2003. Water quality-Guidance standard for the routine sampling and pre-treatment of benthic diatoms from rivers. European Standard EN 13946. European Committee for Standardization, Brussels, $14 \mathrm{pp}$.

EUROPEAN COMMITTEE FOR STANDARIZATION. 2004. Water quality-Guidance standard for the identification, enumeration and interpretation of benthic diatom samples from running waters. European Standard prEN 14407. European Committee for Standardization, Brussels, $12 \mathrm{pp}$.

GAUL, U., U. GEISSLER, M. HENDERSON, R. MAHONEY \& CH. W. REIMER. 1993. Bibliography on the fine-structure of diatom frustules (Bacillariophyceae). Proc. Acad. Nat. Sci. Philadelphia, 144: 69:238

GEITLER, L. 1932. Der Formwechsel der Pennaten Diatomeen (Kieselalgen). Arch. Protistenk., 78: 1226.

GERMAIN, H. 1981. Flore des Diatomées des eaux douces et sâumatres du Massif Armoricain et 
des contrées voisines d'Europe occidentale. Ed. Boubée. Paris, 444 pp.

GOMÀ, J., R. ORTIZ, J. CAMBRA \& L. ECTOR. 2004. Water quality evaluation in Catalonian Mediterranean Rivers using epilithic diatoms as bioindicators. Vie Milieu, 54(2/3): 81-90.

GOMÀ, J., F. RIMET, J. CAMBRA, L. HOFFMANN \& L. ECTOR. 2005. Diatom communities and water quality assessment in mountain rivers of the upper Segre basin (La Cerdanya, Oriental Pyrenees). Hydrobiologia, 511: 209-225.

GONZÁLEZ-GUERRERO, P. 1942. Algas del norte y centro de España. An. J. Bot. Madrid, 3: 269-278.

GRUNOW, A. 1862. Die österreichischen Diatomaceen. Linnaeus Press. Amsterdam. Reprint 1971. 588 pp.

HUSDTEDT, F. 1930. Die Süsswasser-Flora Mitteleuropas. Heft 10: Bacillariophyta (Diatomaceae). Reprint 1976. Otto Koeltz Science Publishers. Königstein. 466 pp.

HUSTEDT, F. 1938-1939. Systematische und ökologische Untersuchungen über die Diatomeenflora von Java. Bali und Sumatra. Arch. Hydrobiol. Suppl., 15: 131-177, 187-295, 393-506, 638-790, 16: 1-155, 274-394.

HUSDTEDT, F. 1957. Die Diatomeenflora des Fluss-Systems der Weser im Gebiet der Hansestadt Bremen. Reprint 1957. Otto Koeltz Science Publishers. Königstein. 260 pp.

HUSDTEDT, F. 1959. Die Kieselalgen Deutschlands, Österreichs und der Schweiz unter Berücksichtigung der übrigen Länder Europas sowie der angrenzenden Meeresgebiete. 2 Teil. Reprint 1977. O. Koeltz Science Publishers. 845 pp.

KOBAYASI, H., K. ANDO \& T. NAGUMO. 1981. On some endemic species of the genus Eunotia in Japan. Ross, R. (ed.): 93-114. Budapest, O. KOELTZ Publ. Königstein. Proc $6^{\text {th }}$ Symp. on Recent and Fossil Diatoms. Budapest Sept. 80.

KRAMMER, K. \& H. LANGE-BERTALOT. 1991. Bacillariophyceae 3. Teil: Centrales, Fragilariaceae, Eunotiaceae. Süßwasserflora von Mitteleuropa 2/3. Gustav Fischer Verlag. Jena. 576 pp.

LANGE-BERTALOT, H. \& D. METZELTIN 1996. Indicators of Oligotrophy. 800 taxa representative of three ecologically distinct lake types. Carbonate buffered-Oligodystrophic-Weakly buffered soft water. Lange-Bertalot, H. (2). Königstein, Koeltz Scientific Books. Iconographia Diatomologica. 390pp.

LECOINTE, C., M. COSTE \& J. PRYGIEL. 1993. "OMNIDIA": software for taxonomy, calculation of diatom indices and inventories management. Hydrobiologia, 269/270: 509-513.

LECOINTE, C., M. COSTE, J. PRYGIEL et L. ECTOR. 1999. Le logiciel OMNIDIA version 2, une puissante base de données pour les inventaires de diatomées et pour le calcul des indices diatomiques européens. Cryptog. Algol, 20: 132134.

MANN, D. G. 1984. An ontogenetic approach to diatoms systematics. In Mann, D. G. (ed.):113144. Proceedings of the $7^{\text {th }}$ International Diatom Synposium. O. Koeltz, Königstein.

MANN, D. G., V. A. CHEPURNOV \& M. IDEI. 2003. Mating system, sexual reproduction, and auxosporulation in the anomalus raphid diatom Eunotia (Bacillariophyta). J. Phycol., 39: 10671084.

MARGALEF, R. 1946. Contribución al conocimiento de las algas del País Vasco-Navarro. Estación de Estudios Pirenaicos. Aportaciones al estudio de la flora y fauna vasco-navarras (Sierra de Aralar): 7-44. Zaragoza.

MARGALEF, R. 1950. Datos para la hidrobiología de la Cordillera Cantábrica, especialmente del Macizo de los Picos de Europa. Publ. Inst. Biol. Apl., 7: 37-76.

MARGALEF, R. 1956a. Materiales para una flora de las algas del NE de España. VI. Collectanea Botanica, 4: 319-329.

MARGALEF, R. 1956b. Algas de agua dulce del Noroeste de España. Publ. Inst. Biol. Apl., 32: 43152.

MARGALEF, R. 1958. Materiales para el estudio de las comunidades bióticas de las aguas dulces y salobres, principalmente del NE de España. Publ. Inst. Biol. Apl., 28: 5-47.

MAYAMA, S. 1992. Morphology of Eunotia multiplastidica sp. nov. (Bacillariophyceae) examined throughout the life cycle. The Korean Journal of Phycology, 7(1):45-54.

MAYAMA, S. 1997. Eunotia valida and E. pseudovalida spec. nov. (Bacillariophyceae): Ultrastructure of the valve and girdle. Nova Hedwigia, 65: 165-176.

MAYAMA, S. \& H. KOBAYASI. 1991. Observations of Eunotia arcus Ehr., type species of the genus Eunotia (Bacillariophyceae). The Japanese Society of Phycology, 39(2): 131-141.

METZELTIN, D. \& H. LANGE-BERTALOT. 1998. Tropical diatoms of South America I. About 700 
predominantly rarely known or new taxa representative of the neotropical flora (= Tropische Diatomeen in Sudamerika I. 700 uberwiegend wenig bekannte oder neue Taxa reprasentativ als Elemente der neotropische Flora). (5). Koeltz. Iconographia Diatomologica. Lange-Bertalot, H. 695 pp.

METZELTIN, D. und A. WITKOWSKI. 1996. Diatomeen der Baren-Insel. Süsswasser und marine Arten. In: Lange-Bertalot, H. (ed.). Iconographia Diatomologica. Annoted Diatom Micrographs. Vol. 4. 232 pp.

MEYBECK, M. 1986. Composition chimique des ruisseaux non pollués de France. Bull. Sci. Geol., 39: 3-77.

OKUNO, H. 1974. Diatomenschalen im Elektronenmikroskopischen Bild. Teil IX. Freshwater Diatoms. J. Cramer. Lehre. 45 pp.

OLIVEIRA DE, P. E. \& M. STEINITZ-KANNAN. 1992. The diatom flora (Bacillariophyceae) of the Cuyabeno Faunistic Reserve, Ecuadorian Amazonia. Nova Hedwigia, 54: 515-552.

PATRICK, R. 1948. Factors effecting the distribution of diatoms. Botan. Review, 14: 473-524.

PATRICK, R. \& C. W. REIMER. 1966. The diatoms of the United States. I. Monographs of the Academy of Natural Sciences of Philadelphia. Sutterhouse. Litiz. Pennsylvania. 688 pp.

PATRICK, R., C. W. REIMER \& G. S. YONG. 1975. The Diatoms of the United States. Monographs of the Academy of Natural Sciences of Philadelphia. Sutterhouse. Litiz. Pennsylvania. 213 pp.

PETERSEN, J. B. 1950. Observations on some small species of Eunotia. Dansk Bot. Archiv., 14: 1-19.

PIERRE, J. F. 1996. Communauté algale et acidité des ruisseaux du massif vosgien. Bull. Acad. Soc. Lor. Sci., 35: 139-156.

PRYGIEL, J. \& M. COSTE. 1993. The assessment of water quality in the Artois-Picardie basin (France) by the use of diatom indices. Hydrobiologia, 269/270: 343-349.

ROUND, F. E., R. M. CRAWFORD \& D. G. MANN. 1990. The diatoms. Biology and Morphology of the Genera. Cambridge University Press, Cambridge. $747 \mathrm{pp}$.

ROUND, F. E. 1972. The problem of cell size during diatom cell division. Nova Hedwigia, 23: 291-303.

SABATER, S. 2000. Diatom communities as indicators of environmental stress in the Guadiamar Ri- ver, S.-W. Spain, following a major mine tailings spill. J. Appl. Phycol., 12: 113-124.

SALA, S. E., S. R. DUQUE, M. NÚÑEZ-AVELLANEDA \& A. A. LAMARO. 2002. Diatoms from the Colombian Amazon: Some species of the genus Eunotia (Bacillariophyceae). Acta Amazonica, 32(4): 589-603.

SCHOEMAN, F. R. 1973. A systematical and ecological study of the Diatom flora of Lesotho with special reference to the water quality. V \& R. Printers. Pretoria. 355 pp.

SLÀDEČEK, V. 1986. Diatoms as indicators of organic pollution. Acta Hydrochim. Hydrobiol., 14: 555-566.

STEINMAN, A. D. \& R. G. SHEATH. 1984. Morphological variability of Eunotia pectinalis (Bacillariophyceae) in a softwater Rhode Island Stream and in culture. J. Phycol., 20: 266-276.

TISON, J., Y. S. PARK, M. COSTE, J. G. WASSON, F. RIMET, L. ECTOR \& F. DELMAS. 2007. Predicting diatom reference communities at the French hydrosystem scale: A first step towards the definition of the good ecological status. Ecological Modelling, 203: 99-108.

TORGAN, L. C. e O. M. DELANI. 1988. Estudo taxonómico de diatomaceas (Bacillariophyceae) do "Complexo Banhado Grande", Rio Grande do Sul, Brasil: represantantes do genero Eunotia Ehrenberg. Iheringia ser.Bot., Porto Alegre, 38: 81-107.

TRÚAN, A. 1885. Ensayo sobre la synopsis de las diatomeas de Astúries, II. An. Soc. Esp. Hist. Nat., 14: 239-256.

VAN DAMM, H., A. MERTENS \& J. SINKELDAM. 1994. A coded checklist and ecological indicator values of freshwater diatoms from the Netherlands. Netherlands J. Aquat. Ecol., 28: 117-133.

VAN HEURCK, H. 1880-1885. Synopsis des Diatomées de Belgique. Atlas. Anvers. Reprint 1981. Linnaeus Press. Amsterdam. 120 pp.

VAN LANDINGHAM, S. 1969. Catalogue of the fossil and recent genera and species of Diatoms and their synonyms 3: 1087-1756. Verlag von J. Cramer. Lehre.

WEST, G. S. 1911. Algological notes, I. J. Bot., 49: 82-89.

ZELINKA, M. \&P. MARVAN. 1961.ZurPräzisierung der biologischen Klassification der Reinheit fliessender Gewässer. Arch Hydrobiol., 19: 159-174. 